\title{
Failure to Shut Off
}

National Cancer Institute

\section{Source}

National Cancer Institute. Failure to Shut Off. NCI Thesaurus. Code C62988.

Problem associated with the device not powering off when a shut down was requested. 